\title{
Role of brassinolide and spraying stages in Zea mays plant
}

Autor:

Ahmed J. M. Habeeb (1)

Intsar H. H. Al-Hilfy (2)

\section{ARTÍCULO DE INVESTIGACIÓN} CIENTÍFICA Y TECNOLÓGICA

How to cite this paper:

Habeeb A J M, and Al-Hilfy I H H., Role of brassinolide and spraying stages in Zea mays plant. Innovaciencia Facultad de Ciencias Exactas, Naturales y Agropecuarias. 2018; 6(1) S1:1-8.

Reception date:

Received: 22 May 2018

Accepted: 30 July 2018

Published Online: 28 December 2018

DOI:

http://dx.doi.org/10.15649/2346075X.474

\section{ABSTRACT}

Introduction: A Field experiment was conducted at the experimental farm, Dept. of Field Crop (Al-Jadriya), Coll. of Agric., Univ. of Baghdad to study the effects of brassinolide concentrations and spraying stages on yield and its components of maize (Baghdad 3 cultivar) during spring and autumn seasons in 2017. Materials and Methods: A randomized complete blocks design arranged in factorial experiment was used with three replicates. The first factor included three concentrations $\left(0,2\right.$ and $\left.4 \mathrm{mg} \mathrm{L}^{-1}\right)$ of brassinolide, and the second factor included spraying stages $(4,8,12,4+8,4+$ 12 , and $8+12$ leaves) using the same concentrations for each stage. Results and discussion: Results showed that the concentration 4 $\mathrm{mg} \mathrm{L} \mathrm{L}^{-1}$ gave the highest grain yield (6.59 and $\left.7.15 \mathrm{tha}^{-1}\right)$ for its superiority in 500 grain weight (102.74 and $112.26 \mathrm{~g}$ ) and number of ears per plant (1.43 and 1.44 ear) for both spring and autumn seasons, respectively. The spraying stage $(4+8$ leaves $)$ recorded highest grain yield (6.33 and $6.77 \mathrm{t} \mathrm{ha}^{-1}$ ), and 500 grain weight (104.73 and $119.20 \mathrm{~g}$ ) for both spring and autumn seasons, respectively. The effect of interaction for both factors was significant in most studied traits. Conclusion: Therefore, we recommend spraying Brassinolide in a concentration of $4 \mathrm{mg} \mathrm{L}^{-1}$ at the stage $4+8$ leaves to increase grain yield of maize.

Keywords:

Maize; Brassinolide; concentration; spraying, stage.

(1) Office of Agricultural Research, Ministry of Agriculture, Baghdad, Iraq, email: dr.intsar_hadi@yahoo.com.

(2) Department of Field Crops Science, College of Agriculture, University of Baghdad, 


\section{INTRODUCTION}

Maize (Zea mays L.) is one of the most important and strategic cereal crop in Iraq and the world, for its high production and multi uses ${ }^{(1)}$. It is a major source of food for both human and animal worldwide.

In Iraq it ranks third after wheat and rice. Maize production in Iraq is about 182300 ton of grains from 53300 hectare ${ }^{(2)}$. Improving the growth and yield of maize relies on better crop management, and the use of plant regulators is considered one of them.

Brassinolide is recognized as a noval group of phytohormones that regulates plant growth and productivity $\stackrel{(3.4)}{2}$, influences many physiological processes (cells division and expansion), pollen tube development,and enhancement of plant defense system against environmental stresses ${ }^{(5)}$. Applicationof brassinolide to maize plant influences both total yield and yield parameters, depending on the stage it was applied and concentrations used $\stackrel{(6,7)}{ }$.

Maize plants treated with $0.25 \mathrm{mg} \mathrm{L}^{-1}$ brassinolide showed significant increase in number of ears per plant, grains per plant, and 100 grain weight ${ }^{(8)}$. Foliar spraying of brassinolide $\left(0.1 \mathrm{mg} \mathrm{L}^{-1}\right)$ improved number of ears per plant, number of grains per ear, number of grains per row, 100 grain weight, and grain yield ${ }^{(9)}$. Spraying brassinosteroids on maize plants at 3-4 leaves stage with $100 \mathrm{~g} \mathrm{ha}^{-1}$ caused an increase in

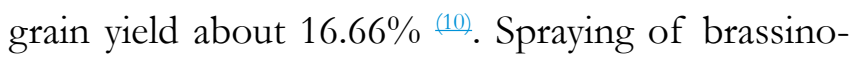
lide at two different stages in a concentration of 0.35 $\mathrm{mg} \mathrm{L}^{-1}$ caused an increase in the number of grains in ear $(34 \%)$ compared to control treatment ${ }^{(8)}$. Brassinolide foliar application at tasseling regulated kernel endosperm cell division and increased the number of kernel endosperm cells by $6.2-40.4 \%$, resulting in a high grain filling rate, high kernel weight, and in-

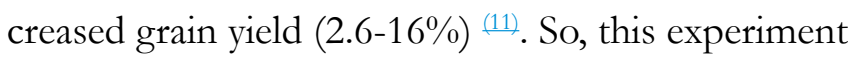

was conducted to determine the best concentration and suitable spraying stage to spray brassinolide in order to get high yield of maize under field conditions.

\section{MATERIAL AND METHODS}

A field experiment was conducted during spring and autumn seasons in 2017 at the farm of Field Crop Department, College of Agriculture, University of Baghdad, Iraq, located at latitude of $33^{\circ} .32^{\prime} \mathrm{N}$ and longitude of $44^{\circ} .23^{\prime} \mathrm{E}$ to study the response of maize yield to different concentrations of brassinolide spraying at different spraying stages. The layout of the experiment was Randomized Complete Blocks Design in factorial arrangement with three replications. The treatments were three brassinolide concentrations $\left(0,2\right.$, and $\left.4 \mathrm{mg} \mathrm{L}^{-1}\right)$ and six spraying stages $(4,8,12,4+8,4+12$, and 8+12 leaves). Synthetic cultivar (Baghdad -3) seeds were sown on 223-2017 and 29-7-2017 at a rate of 53.333 plant ha-1 for both seasons. Plots area was $18 \mathrm{~m}^{2}$ (six rows, each of four meters long, $75 \mathrm{~cm}$ apart, and $25 \mathrm{~cm}$ within the plants). Recommended rate of nitrogen $(696 \mathrm{~kg}$ $\left.\mathrm{ha}^{-1}\right)$ was applied in a form of urea $(46 \% \mathrm{~N})$ in two split equal doses (at 20 days after emergence and after 15 days from first application), while, phosphorus was added at planting time in a form of tri super phosphate $\left(\mathrm{P}_{2} \mathrm{O}_{5} 46 \%\right)$ in a rate of $436 \mathrm{~kg} \mathrm{ha}^{-1} \stackrel{(12)}{ }$. At harvest time (15-7-2017 and 18-11-2017), two central rows in each plot were harvested to determine the grain yield for these two rows, and then the yield per hectare was calculated. Sub samples of 10 plants were taken from each plot to measure the number of ears plant ${ }^{-1}$, number of rows ear ${ }^{-1}$, number of grains per row, number of grains per ear, and 500 grain weight. The least significant differences (L.S.D.) at the level of 0.05 probability was employed to compare the differences among treatments means $\frac{(13)}{\text {. }}$. 


\section{RESULTS AND DISCUSSION}

1- No. of ears plant ${ }^{-1}$

Results in Table 1 indicates that the effect of brassinolide spraying concentrations, spraying stages, and their interaction had a significant effect on the number of ears plant ${ }^{-1}$ and the concentration $4 \mathrm{mg} \mathrm{L}^{-1}$ gave the highest number of ears (1.43 and 1.44 ear) for both spring and autumn seasons, respectfully. The increase in this trait with increasing brassinolide concentration might be due to its role in the induction of vascular system differentiation by increasing the number and size of the vascular system, so it simulates xylem differentiation and inhibits the differentiation of phloem, and consequently increases the translocation of water and nutrients $\frac{(14)}{\text {. }}$.

Regarding spraying stages, results in Table 1 show that the highest values (1.39 and 1.45 ear plant $^{-1}$ ) were recorded at $4+8$ leaves stage compared to those obtained from 4 leaves stage which produced 1.24 and 1.30 ear plant ${ }^{-1}$ for both seasons, respectively, and this could be due to the initiation and development of ears primordia during the $4+8$ leaves spraying stage ${ }^{(1)}$. As for the interaction, the highest means (1.55 and 1.58 ear plant $\left.{ }^{-1}\right)$ were recorded with the concentration of $4 \mathrm{mg} \mathrm{L}^{-1}$ and $4+8$ leaves stage during both seasons, respectively.

Table 1. Number of ears plant ${ }^{-1}$ of maize as affected by brassinolide concentrations, spraying stages, and their interaction during spring and autumn seasons in 2017.

\begin{tabular}{|c|c|c|c|c|c|c|c|c|}
\hline \multicolumn{5}{|c|}{ Spring season } & \multicolumn{4}{|c|}{ Autumnseason } \\
\hline \multirow{2}{*}{ Spraying stages } & \multicolumn{3}{|c|}{$\begin{array}{l}\text { concentrations } \\
\left(\mathrm{mg} \mathrm{L}^{-1}\right) \text { Spraying }\end{array}$} & \multirow{2}{*}{$\begin{array}{c}\text { Spraying } \\
\text { stages } \\
\text { means }\end{array}$} & \multicolumn{3}{|c|}{$\begin{array}{l}\text { concentrations } \\
\left(\mathrm{mg} \mathrm{L}^{-1}\right) \text { Spraying }\end{array}$} & \multirow{2}{*}{$\begin{array}{c}\text { Spraying } \\
\text { stages } \\
\text { means }\end{array}$} \\
\hline & 0 & 2 & 4 & & 0 & 2 & 4 & \\
\hline 4 leaves & 1.16 & 1.27 & 1.30 & 1.24 & 1.21 & 1.32 & 1.37 & 1.30 \\
\hline 8leaves & 1.19 & 1.36 & 1.40 & 1.31 & 1.35 & 1.37 & 1.39 & 1.37 \\
\hline 12 leaves & 1.17 & 1.31 & 1.44 & 1.30 & 1.30 & 1.41 & 1.40 & 1.37 \\
\hline $4+8$ leaves & 1.21 & 1.43 & 1.55 & 1.39 & 1.31 & 1.46 & 1.58 & 1.45 \\
\hline $4+12$ leaves & 1.20 & 1.30 & 1.48 & 1.32 & 1.30 & 1.42 & 1.48 & 1.40 \\
\hline $8+12$ leaves & 1.23 & 1.42 & 1.43 & 1.36 & 1.32 & 1.40 & 1.44 & 1.38 \\
\hline L.S.D. $0.05 \%$ & \multicolumn{3}{|c|}{0.10} & 0.05 & \multicolumn{3}{|c|}{0.07} & 0.04 \\
\hline $\begin{array}{c}\text { Concentrations } \\
\text { means }\end{array}$ & 1.19 & 1.34 & 1.43 & & 1.29 & 1.39 & 1.44 & \\
\hline L.S.D. 0.05 & \multicolumn{3}{|c|}{0.04} & \multicolumn{5}{|c|}{0.02} \\
\hline
\end{tabular}

\section{2- No. of rows ear ${ }^{-1}$}

Results in Table 2 clearly show that the effect of brassinolide concentrations, spraying stages, and their interaction had non-significant effect on the number of rows ear ${ }^{-1}$ for both study seasons. 
Table 2. Number of rows ear ${ }^{-1}$ of maize as affected by brassinolide concentrations, spraying stages, and their interaction during spring and autumn seasons in 2017.

\begin{tabular}{|c|c|c|c|c|c|c|c|c|}
\hline \multicolumn{5}{|c|}{ Spring season } & \multicolumn{4}{|c|}{ Autumnseason } \\
\hline \multirow{2}{*}{ Spraying stages } & \multicolumn{3}{|c|}{$\begin{array}{l}\text { concentrations } \\
\left(\mathrm{mg} \mathrm{L}^{-1}\right) \text { Spraying }\end{array}$} & \multirow{2}{*}{$\begin{array}{c}\text { Spraying } \\
\text { stages } \\
\text { means }\end{array}$} & \multicolumn{3}{|c|}{$\begin{array}{l}\text { concentrations } \\
\left(\mathrm{mg} \mathrm{L}^{-1}\right) \text { Spraying }\end{array}$} & \multirow{2}{*}{$\begin{array}{c}\text { Spraying } \\
\text { stages } \\
\text { means }\end{array}$} \\
\hline & 0 & 2 & 4 & & 0 & 2 & 4 & \\
\hline 4 leaves & 14.33 & 15.00 & 14.33 & 14.55 & 15.00 & 15.33 & 15.00 & 15.11 \\
\hline 8 leaves & 14.66 & 14.33 & 14.66 & 14.55 & 15.00 & 15.00 & 15.33 & 15.11 \\
\hline 12 leaves & 14.33 & 15.33 & 14.33 & 14.66 & 15.00 & 15.66 & 15.33 & 15.33 \\
\hline $4+8$ leaves & 14.00 & 14.33 & 14.33 & 14.22 & 15.00 & 15.33 & 14.66 & 15.00 \\
\hline $4+12$ leaves & 14.33 & 14.33 & 14.33 & 14.33 & 15.33 & 15.33 & 15.00 & 15.22 \\
\hline $8+12$ leaves & 14.00 & 14.66 & 15.00 & 14.55 & 15.00 & 15.00 & 14.66 & 14.88 \\
\hline L.S.D 0.05 & & N.S & & N.S & & N.S & & N.S \\
\hline $\begin{array}{c}\text { Concentrations } \\
\text { means }\end{array}$ & 14.27 & 14.66 & 14.50 & & 15.05 & 15.27 & 15.00 & \\
\hline L.S.D 0.05 & & N.S & & & & N.S & & \\
\hline
\end{tabular}

\section{3-No. of grains row $^{-1}$}

Results from Table 3 show significant differences in the number of grains row-1 due to different spraying concentrations and the interaction between spraying concentrations and spraying stages for both seasons. The concentration $2 \mathrm{mg} \mathrm{L}^{-1}$ gave the highest values of grains row-1 (38.09 and 39.38 grain) compared to control treatment which gave lowest values (36.27 and 37.25 grain) for both spring and autumn seasons, respectively. This increase might be due to the role of brassinolide in the simulation of pollen tube growth, resulting in an increased fertility percentage ${ }^{(15)}$. These results are in agreement with those obtained by Anjum et al. ${ }^{(2)}$ who found an increase in the number of grains row-1 as a result of brassinolide spraying.

Table 3. Number of grains row $^{-1}$ of maize as affected by brassinolide concentrations, spraying stages, and their interaction during spring and autumn seasons in 2017.

\begin{tabular}{|c|c|c|c|c|c|c|c|c|}
\hline \multicolumn{5}{|c|}{ Spring season } & \multicolumn{4}{|c|}{ Autumnseason } \\
\hline \multirow{2}{*}{ Spraying stages } & \multicolumn{3}{|c|}{$\begin{array}{l}\text { concentrations } \\
\left(\mathrm{mg} \mathrm{L}^{-1}\right) \text { Spraying }\end{array}$} & \multirow{2}{*}{$\begin{array}{c}\text { Spraying } \\
\text { stages } \\
\text { means }\end{array}$} & \multicolumn{3}{|c|}{$\begin{array}{l}\text { concentrations } \\
\left(\mathrm{mg} \mathrm{L}^{-1}\right) \text { Spraying }\end{array}$} & \multirow{2}{*}{$\begin{array}{c}\text { Spraying } \\
\text { stages } \\
\text { means }\end{array}$} \\
\hline & 0 & 2 & 4 & & 0 & 2 & 4 & \\
\hline 4 leaves & 36.00 & 38.40 & 37.00 & 37.40 & 36.00 & 39.66 & 39.00 & 38.22 \\
\hline 8 leaves & 36.33 & 38.10 & 37.66 & 37.36 & 37.40 & 39.00 & 39.00 & 38.46 \\
\hline 12 leaves & 36.66 & 37.00 & 37.33 & 36.99 & 37.16 & 39.00 & 38.66 & 38.27 \\
\hline $4+8$ leaves & 36.00 & 38.33 & 38.00 & 37.44 & 37.62 & 39.33 & 39.00 & 38.65 \\
\hline $4+12$ leaves & 36.66 & 38.32 & 37.66 & 37.54 & 37.36 & 39.33 & 39.00 & 38.56 \\
\hline $8+12$ leaves & 36.00 & 38.66 & 37.33 & 37.15 & 38.00 & 40.00 & 38.33 & 38.77 \\
\hline L.S.D 0.05 & & 1.06 & & N.S & & 0.95 & & 0.55 \\
\hline $\begin{array}{c}\text { Concentrations } \\
\text { means }\end{array}$ & 36.27 & 38.09 & 37.49 & & 37.25 & 39.38 & 38.83 & \\
\hline L.S.D 0.05 & & 0.43 & & & & 0.39 & & \\
\hline
\end{tabular}


Regarding the spraying stages, results in Table 3 show that the effect on this trait was significant during autumn season only. Highest mean was obtained with 8+12 leaves stage (38.77 grain) during autumn season, which differed significantly only from 4 leaves stage. This might be due to the role of brassinolide spraying in increasing the fertility and activity of pollen grains at late growth stages, resulting in an increase in the number of grains row $^{-1} \stackrel{(15)}{\text {. As shown }}$ in Table 3 the interaction between $2 \mathrm{mg} \mathrm{L}^{-1}$ and the treatment $8+12$ leaves stage recorded highest values (38.66 and 40.00 grain) in comparison with control at 4 leaves stage which recorded lowest values $(36.00$ and 36.00 grain) for both seasons, respectively.

\section{4- Number of grains ear ${ }^{-1}$}

It is noted from Table 4 that the effect of brassinolide was significant in both seasons, whereas the effect of spraying stages and the interaction between the two factors was non-significant on this trait for both seasons. Maize plants sprayed with $2 \mathrm{mg} \mathrm{L}^{-1}$ Showed significant increase in this trait (558.41 and 601.59 grain ear $\left.^{-1}\right)$, whereas plants in control treatment recorded lowest means (517.85 and 560.90 grain ear $^{-1}$ ) for both seasons, respectively. This increase in this trait with spraying $2 \mathrm{mg} \mathrm{L}^{-1}$ of brassinolide could be due to the role of brassinolide in improving vegetative growth and chlorophyll formation, delay in leaves senescence, and an increase in the number of florets, and consequently an increase in the final grain yield of the plants $\stackrel{(16)}{ }$. In addition, brassinolide had a positive role in increasing the number of grains row $^{-1}$ (table 3). These results are in agreement with those obtained by $\stackrel{(71)}{\longrightarrow}$ who found an increase in the number of grains ear ${ }^{-1}$ due to brassinolide application.

Table 4. Number of grains ear ${ }^{-1}$ of maize as affected by brassinolide concentrations, spraying stages, and their interaction during spring and autumn seasons in 2017.

\begin{tabular}{|c|c|c|c|c|c|c|c|c|}
\hline \multicolumn{5}{|c|}{ Spring season } & \multicolumn{4}{|c|}{ Autumnseason } \\
\hline \multirow{2}{*}{ Spraying stages } & \multicolumn{3}{|c|}{$\begin{array}{l}\text { concentrations } \\
\left(\mathrm{mg} \mathrm{L}^{-1}\right) \text { Spraying }\end{array}$} & \multirow{2}{*}{$\begin{array}{c}\text { Spraying } \\
\text { stages } \\
\text { means }\end{array}$} & \multicolumn{3}{|c|}{$\begin{array}{l}\text { concentrations } \\
\left(\mathrm{mg} \mathrm{L}^{-1}\right) \text { Spraying }\end{array}$} & \multirow{2}{*}{$\begin{array}{c}\text { Spraying } \\
\text { stages } \\
\text { means }\end{array}$} \\
\hline & 0 & 2 & 4 & & 0 & 2 & 4 & \\
\hline 4 leaves & 515.88 & 579.90 & 530.21 & 541.99 & 540.00 & 607.98 & 585.00 & 577.66 \\
\hline 8 leaves & 532.59 & 545.97 & 552.09 & 543.55 & 561.00 & 585.00 & 597.87 & 581.29 \\
\hline 12 leaves & 525.33 & 567.21 & 534.93 & 542.49 & 557.40 & 610.74 & 592.65 & 586.93 \\
\hline $4+8$ leaves & 504.00 & 549.26 & 544.54 & 532.60 & 564.30 & 602.92 & 571.74 & 579.65 \\
\hline $4+12$ leaves & 525.33 & 549.12 & 539.66 & 538.04 & 572.72 & 602.92 & 585.00 & 586.88 \\
\hline $8+12$ leaves & 504.00 & 558.98 & 559.95 & 540.97 & 570.00 & 600.00 & 561.91 & 577.30 \\
\hline L.S.D 0.05 & & N.S & & N.S & & N.S & & N.S \\
\hline $\begin{array}{c}\text { Concentrations } \\
\text { means }\end{array}$ & 517.85 & 558.41 & 543.56 & & 560.90 & 601.59 & 582.36 & \\
\hline L.S.D 0.05 & & 15.79 & & & & 11.70 & & \\
\hline
\end{tabular}




\section{5-500 grain weight $(\mathrm{g})$}

Results in Table 5 show that there were significant differences in 500 grain weight regarding brassinolide concentrations, spraying stages, and the interaction between them for both spring and autumn seasons. The highest grain weight was recorded with $4 \mathrm{mg} \mathrm{L}^{-1}$ (102.74 and $112.26 \mathrm{~g}$ ), while the lowest values were noticed with control treatment (91.65 and $100.22 \mathrm{~g}$ ), for both autumn and spring seasons, respectively. This might be attributed to the role of brassinolide in genes coding of gibberellin and auxins which affects endosperm cells division and elongation, and the increase in the efficiency of assimilates translocation that finally causes an increase in 500 grain weight ${ }^{(11)}$. This result is in agreement with Anjum et al. $\stackrel{(2)}{ }$ and Dana Hola et al. $\stackrel{(6)}{~}$.

Regarding spraying stages, results in Table 5 show that $4+8$ leaves stage recorded highest grain weight (104.73 and $119.20 \mathrm{~g}$ ) in comparison with 4 leaves stage treatment which gave lowest values (94.37 and $106.33 \mathrm{~g}$ ) for both spring and autumn seasons, respectively. The reason for increasing seeds weight when sprayed with brassinolide might be due to the synchronization of the spraying time with the growth and expansion of leaves, as well as its positive role in all biological processes inside the plants and the increase in the dry weight of the roots and then the increase in the absorption of nutrients and photosynthesis $\stackrel{(3)}{~}$. This result is in agreement with the results obtained by many authors who found that spraying of brassinolide caused an increase in maize grain weight $\frac{(8,217)}{2}$. Regarding the interaction, the combination $4 \mathrm{mg} \mathrm{L}^{-1}$ and 4+8 leaves stage recorded highest means (111.98 and $119.20 \mathrm{~g}$ ), while the control with 4 leaves gave the lowest values $(88.00$ and $96.00 \mathrm{~g}$ ) for both spring and autumn seasons, respectively.

Table 5. 500 grain weight (g) of maize as affected by brassinolide concentrations, spraying stages, and their interaction during spring and autumn seasons in 2017.

\begin{tabular}{|c|c|c|c|c|c|c|c|c|}
\hline \multicolumn{5}{|c|}{ Spring season } & \multicolumn{4}{|c|}{ Autumnseason } \\
\hline \multirow{2}{*}{ Spraying stages } & \multicolumn{3}{|c|}{$\begin{array}{l}\text { concentrations } \\
\left(\mathrm{mg} \mathrm{L}^{-1}\right) \text { Spraying }\end{array}$} & \multirow{2}{*}{$\begin{array}{c}\text { Spraying } \\
\text { stages } \\
\text { means }\end{array}$} & \multicolumn{3}{|c|}{$\begin{array}{l}\text { concentrations } \\
\left(\mathrm{mg} \mathrm{L}^{-1}\right) \text { Spraying }\end{array}$} & \multirow{2}{*}{$\begin{array}{c}\text { Spraying } \\
\text { stages } \\
\text { means }\end{array}$} \\
\hline & 0 & 2 & 4 & & 0 & 2 & 4 & \\
\hline 4 leaves & 88.00 & 96.00 & 99.13 & 94.37 & 96.00 & 104.00 & 106.33 & 106.33 \\
\hline 8 leaves & 91.00 & 98.33 & 97.33 & 95.55 & 99.00 & 107.67 & 108.61 & 108.61 \\
\hline 12 leaves & 92.33 & 9767 & 103.00 & 97.66 & 100.33 & 108.15 & 111.57 & 111.57 \\
\hline $4+8$ leaves & 94.22 & 108.00 & 111.98 & 104.73 & 102.67 & 116.23 & 119.20 & 119.20 \\
\hline $4+12$ leaves & 93.37 & 100.23 & 104.67 & 99.42 & 101.00 & 113.00 & 115.52 & 115.52 \\
\hline $8+12$ leaves & 91.00 & 96.67 & 100.33 & 96.00 & 102.33 & 108.87 & 112.33 & 112.33 \\
\hline L.S.D 0.05 & & 2.86 & & 1.65 & & 2.98 & & 1.67 \\
\hline $\begin{array}{c}\text { Concentrations } \\
\text { means }\end{array}$ & 91.65 & 99.48 & 102.74 & & 100.22 & 109.65 & 112.26 & \\
\hline L.S.D 0.05 & & 1.17 & & & & 1.81 & & \\
\hline
\end{tabular}




\section{6- Grain yield ( $\left.\mathrm{t} \mathrm{ha}^{-1}\right)$}

Data illustrated in Table 6 show the significant effect of brassinolide, spraying stages, and their interaction on this trait for both seasons. Plants sprayed with 4 $\mathrm{mg} \mathrm{L} \mathrm{L}^{-1}$ produced highest grain yield (6.59 and 7.15 $\left.\mathrm{t} \mathrm{ha}^{-1}\right)$, while plants in the control treatment $(0 \mathrm{mg}$ $\left.\mathrm{L}^{-1}\right)$ produced 5.28 and $5.86 \mathrm{t} \mathrm{ha}^{-1}$ for both spring and autumn seasons, respectively. This increase with $4 \mathrm{mg} \mathrm{L}^{-1}$ might be due to the significant influence of brassinolide on growth parameters (leave area, chlorophyll content, photosynthesis, cell division, and leaves senescence) which caused an increase in the grain yield $(18,19)$. These results are in accordance with those obtained by Dana Hola et al. (6) who found that brassinolide application increased grain yield. Spraying brassinolide at (4+8 leaves) spraying stage significantly recorded highest grain yield (6.33 and $\left.6.77 \mathrm{t} \mathrm{ha}^{-1}\right)$, and this could be attributed to the increase in yield components such as, number of ears plant $^{-1}$ (Table 1), number of grains row ${ }^{-1}$ (Table 3) and number of grains ear-1 (Table 4). These results are in agreement with those obtained by Qing-yan el al. ${ }^{(20)}$ who found an increase in the grain yield due to the increase in yield components.

Table 6: Grain yield (ton ha ${ }^{-1}$ ) of maize as affected by brassinolide concentrations, spraying stages, and their interaction during spring and autumn seasons in 2017.

\begin{tabular}{|c|c|c|c|c|c|c|c|c|}
\hline \multicolumn{5}{|c|}{ Spring season } & \multicolumn{4}{|c|}{ Autumnseason } \\
\hline \multirow{2}{*}{ Spraying stages } & \multicolumn{3}{|c|}{$\begin{array}{l}\text { concentrations } \\
\left(\mathrm{mg} \mathrm{L}^{-1}\right) \text { Spraying }\end{array}$} & \multirow{2}{*}{$\begin{array}{c}\text { Spraying } \\
\text { stages } \\
\text { means }\end{array}$} & \multicolumn{3}{|c|}{$\begin{array}{l}\text { concentrations } \\
\left(\mathrm{mg} \mathrm{L}^{-1}\right) \text { Spraying }\end{array}$} & \multirow{2}{*}{$\begin{array}{c}\text { Spraying } \\
\text { stages } \\
\text { means }\end{array}$} \\
\hline & 0 & 2 & 4 & & 0 & 2 & 4 & \\
\hline 4 leaves & 5.11 & 5.93 & 6.43 & 5.82 & 5.61 & 6.30 & 6.89 & 6.26 \\
\hline 8 leaves & 5.26 & 6.14 & 6.36 & 5.92 & 5.80 & 6.31 & 7.11 & 6.41 \\
\hline 12 leaves & 5.30 & 6.37 & 6.60 & 6.09 & 5.87 & 6.56 & 7.04 & 6.49 \\
\hline $4+8$ leaves & 5.37 & 6.64 & 6.96 & 6.33 & 5.94 & 6.90 & 7.47 & 6.77 \\
\hline $4+12$ leaves & 5.29 & 6.39 & 6.59 & 6.09 & 6.01 & 6.36 & 7.25 & 6.63 \\
\hline $8+12$ leaves & 5.32 & 6.46 & 6.63 & 6.14 & 5.95 & 6.57 & 7.17 & 6.56 \\
\hline L.S.D 0.05 & & 0.15 & & 0.09 & & 0.12 & & 007 \\
\hline $\begin{array}{c}\text { Concentrations } \\
\text { means }\end{array}$ & 5.28 & 6.32 & 6.59 & & 5.86 & 6.50 & 7.15 & \\
\hline L.S.D 0.05 & & 0.06 & & & & 0.05 & & \\
\hline
\end{tabular}

Regarding the interaction, spraying of $4 \mathrm{mg} \mathrm{L}^{-1}$ brassinolide at spraying stage (4+8 leaves) recorded highest grain yield (6.96 and $7.47 \mathrm{t} \mathrm{ha}^{-1}$ ) in comparison with control treatment at spraying stage (4 leaves) which recorded 5.11 and $5.61 \mathrm{t} \mathrm{ha}^{-1}$ for both spring and autumn seasons, respectively.

\section{REFERENCES}

1. Medhat M. EL-Sahookie, Maize Production and Breeding. Ministry of Higher Education and Scientific Research University of Baghdad.1990.

2. Statistical Guide for Field Crop Data. Office of Agricultural Researches Dept. of Agricultural Economy. Second edition. Ministry of Agriculture - Republic of Iraq.2016; pp 64. 
3. Cecile. Vriet, Eugenia. Russinova, and Christophe. Reuzeau. Boosting crop yield with plant steroids. The Plant Cell.2012; (24):842-857.

4. Stutts Lauren, Wang. Yishi, and Stapleton Ann. Plant growth regulators ameliorate orexacerbate abiotic and biotic stress effects on Zea mays kernel weight in agenotype-specific Manner University of North Carolina Wilmington, Wilmington, NC. 2016; 28403.

5. Noha A. E. Aly. Effect of brassinolide or uniconazole on growth, water relation and some metabolic products of maize and faba bean plant grown under saline conditions. Assiut Uni. Staff Thesis. 2007; P229.

6. Dana Hola, Olga Rothova, Marie Kocova, Ladislav Kohout and Miroslav. Kvasnica. The effectof brassinosteroids on the morphology development and yield of field grownmaize. Plant Growth Regul. 2010; 61: 29-43.

7. Baltazar L. T. Ruiz, Alejandro E. Calderon, Moises M. Rodriguez, Jose. Luis Rodriguez-de la, Martha B.I. Garza and Jaime. S. C. Ruiz. Effect de brassinosteroids en hibridos de maiz androesterilesy fertile. Agronomia Mesoamericana. 2007; 18(2): 155-162.

8. Samia M. EL-Khallal, Tahani A. Hathout, A. Ashour, and Abd. Almalik Kerrit .Brassinolide and salicylic acid induced with biochemical activities and productivity of maize plants grown under salt stress. Reseearch Journal Agriculture and biological Sci.2009; 5: (4) 380-390.

9. Anjum, S. A., L. C. Wang, M. Farooq, M. Hussain, L. L. Xue, and C. M. Zou. Brassinolide application improves the drought tolerance in maize through modulation of enzymatic antioxidants and leaf gas exchange. J. Agro. and Crop Sci.2011; 197: (3) 177-185.

10. Thomas. Huster, Growth and yield response of selected crops to treatment with comcat ${ }^{\circledR}$. Theies PhD. Department of Soil, Crop and Climate Sciences, Faculty of Natural and Agricultural Sciences, University of the Free State.2011; P157.

11. Gao, Z., X. G. Liang, L. Zhang, S. Lin, X. Zhao, L. Li -zhou, S. Shen and S. Li-Zhou. Spraying exogenous 6- benzyladenine and Brassinolide at tasseling increases maize yield by enhancing source and sink capacity. Field Crops Research. 2017; 211:1-9.
12. Guidance in the cultivation and production of maize.General Authority for Extension and Agricultural Cooperation - Ministry of Agriculture - Republic of Iraq.2011; pp 16.

13. Steel, G. D., and J. H. Torrie. Principles and Procedures of Statistics. McGraw. Hill book company, Inc. New York .1960.

14. Maky A. AL-Khafaji. Plant Growth Regulators Application and Utilization in Horticulture. Ministry of Higher Education and Scientific Research University of Baghdad College of Agri.2014.

15. Neveen B. Talaat, Bahaa. T. Shawky. Dual application of 24-epibrassinolide and spermine confers drought stress tolerance in maize (Zea mays L.) by modulatingpolyamine and protein metabolism. J Plant Growth Regul.2016; 35 (2): 518-533.

16. Norman B. Best, Thomas. Hartwig, Josh. Budka, Shozo. Fujioka, Gurmukh. Johal, Burkhard. Schulz, and Brian. P. Dilkes. Nana plant Encodes a Maize Ortholog of the Arabidopsis Brassinosteroid Biosynthesis Gene DWARF1 Identifying Developmental Interactions between Brassinosteroids and Gibberellins1. American Society of Plant Biologists. 2016; 171:2633-2647, www. plantphysiol.org.

17. Neveen B. Talaat, Bahaa. T. Shawky, and Agmed. S. Ibrahim. Allevation of drought-induced oxidative stress in maize (Zea mays L.) plant by dual application of 24-epibrassinolide and spermine. Environmental Experimental Botany.2015; 113:47-58.

18. Shamsul Hayat, and Aqil. Ahmed. Brassinosteroide: A Class of Plant Hormone. Springer, Berlin. Germany. 2011.

19. Songlin Hu, Darlene. L. Sanchez, Cuiling. Wang, Alexander. E. Lipka. Yanhai. Yin, Candice. A. C. Gardner and Thomas. Lubbersted. Brassinosteroids and gibberellin control of seedling traits in maize (Zea mays L.). Plant Science.2017; 263: 132-141.

20.Qing-yan, W., G. Dahai, P. Haibo, L. Jianmin, D. Lusheng, Z. Mingcai, and L. Zhaohu .Effects of brassinolide on photosynthetic function and yield of spring maize in grain filling stage. ActaAgronomicaSinica. 2015; 41 (10):1557-1563. 